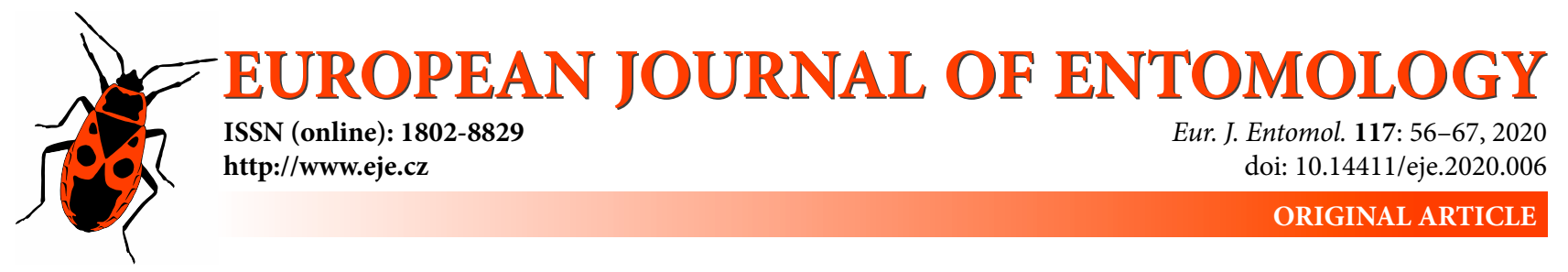

\title{
Long term changes (1990-2016) in carabid beetle assemblages (Coleoptera: Carabidae) in protected forests on Dinaric Karst on Mountain Risnjak, Croatia
}

\author{
ŽELJKA JAMBROŠIĆ VLADIĆ ${ }^{1}$ and LUCIJA ŠERIĆ JELASKA ${ }^{2}$ \\ ${ }^{1}$ Architectural, Natural Science and Mining School Varaždin, Hallerova aleja 3, 42000 Varaždin, Croatia; \\ e-mail: z.j.vladic@gmail.com \\ 2 University of Zagreb, Faculty of Science, Department of Biology, Rooseveltov trg 6, 10000 Zagreb, Croatia; \\ e-mail: slucija@biol.pmf.hr
}

\begin{abstract}
Key words. Coleoptera, Carabidae, climatic changes, elevation gradient, endemic species, repeated study, community
\end{abstract} composition, Croatia

\begin{abstract}
Carabids, as well-known bioindicators, have been used to study the long term changes that have occurred in their communities in the Dinaric Alps. This study involved eight sites in the protected forests of the Risnjak National Park in the years 2015 and 2016 of which three were previously studied in 1990 and 1991 . A total of 9,521 individual ground beetles belonging to 17 genera and 33 species were collected. Species diversity and community composition, including percentages of species grouped according to their habitat preferences, body size, wing morphology, preferred moisture and temperature were used to compare the sites sampled in 1990 and 1991 and resampled in 2015 and 2016 . Even though this study was carried out in protected forests within the National Park with minimal anthropogenic pressure and the fact that available climatic data didn't show any significant change in climate over the last 25 years, there was a reduction in the abundance of specialist species and increase in the spread of generalist species. Furthermore, the lower abundance of a mountain specialist and endemic species, Pterostichus variolatus, and the lack of mountain specialists Molops alpestris, Pterostichus unctulatus and Trechus croaticus in the catches indicate the importance of further monitoring of these mountain forest ecosystems and for a well-timed and appropriate conservation approach.
\end{abstract}

\section{INTRODUCTION}

The rapid loss of biodiversity is a threat to the stability and the existence of the ecosystems we know today. While some claim that we are in the middle of the largest extinction in the Earth's history - Sixth Mass Extinction (Ceballos et al., 2015; Payne et al., 2016), others hope that the situation is overstated (Leather, 2017). Nevertheless, the loss of any form of life in some way affects the functioning of ecosystems (Bradley et al., 2012).

One of the best ways to track changes in biodiversity is the continuous monitoring of well-known insect groups (Briggs, 2017) such as carabids (e.g. Work et al., 2008; Taylor \& Morecroft, 2009; Sklodowski \& Garbalinska, 2011; Blaszkiewicz \& Schwerk, 2013; Homburg et al., 2019). For many years now, carabids have proved to be useful model organisms for monitoring changes in ecosystems caused by various factors (Desender et al., 1994; Heijerman \& Turin, 1994; Maelfait et al., 1994; Niemelä, 2001; Niemelä et al., 2007; Šerić Jelaska et al., 2010, 2014; Schwerk, 2014). The great abundance, ecological diversity, short generation times, relatively high fecundity, sensitivity to environmental changes and well-known life history traits (Lindroth, 1961-1969; Thiele, 1977; Grum, 1986; Lövei \& Sunderland, 1996; Niemelä et al., 2000; Szyszko et al., 2000) make their bioindicator role unquestionable (e.g. Müller-Motzfeld, 1989; Heijerman \& Turin, 1994; Horvatovich, 1994; Maelfait et al., 1994; Pizzolotto, 1994; Eyre et al., 1996; Luff, 1996; Šerić Jelaska \& Durbešić, 2009; Pizzolotto et al., 2013). Their high sensitivity to soil composition, $\mathrm{pH}$ and temperature (Merivee et al., 2004, 2005, 2008; Must et al., 2006) was the main reason why ground-dwelling beetles were considered to be potential early warning indicators (Koivula, 2011). Pizzolotto et al. (2014) refer to carabids as a "day-after warning" due to their ability to signal changes in vegetation before they can be visually observed. Thus, it is not surprising that carabids are being increasingly used to determine modifications in ecosystems caused by changes in climate (e.g. McCarty, 2001; Parmesan \& Yohe, 2003; Harte et al., 2004; Gobbi et al., 2007, 2010, 2011; Brambilla \& Gobbi, 2013; Brandmayr et al., 2013).

Long-term data could help reveal the extent of changes in species diversity, ranges, phenology of life cycles and interactions following environmental changes (such as cli- 


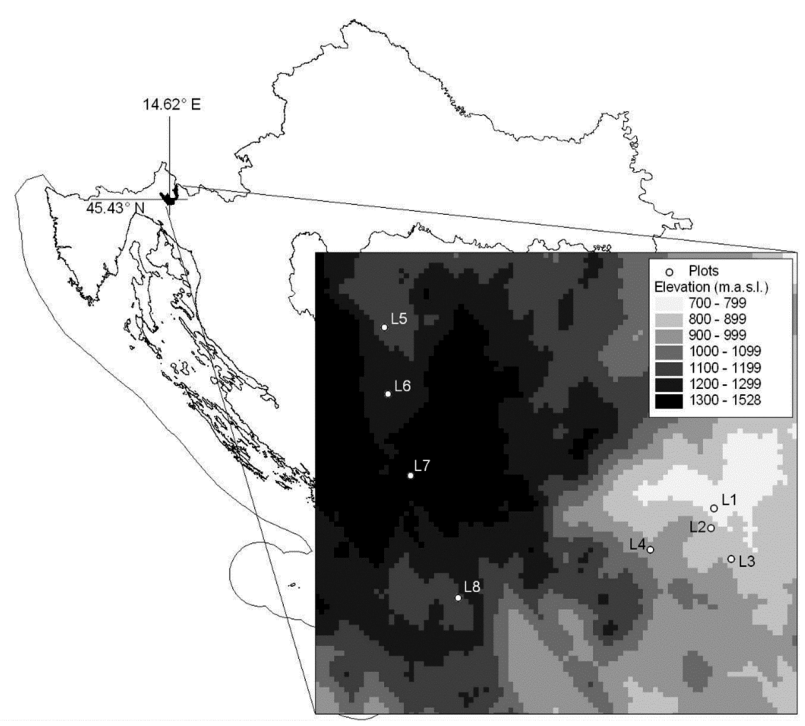

Fig. 1. Map of the area studied and the locations of the sites sampled along an altitudinal gradient on Mt. Risnjak, in Western Croatia. Different shades denote altitude (m a.s.I.).

mate change, habitat destruction, etc.). Therefore, in this paper, we aimed to compare carabid beetle assemblages sampled in the years 1990 and 1991 with those sampled 25 years later (in 2015 and 2016), at the same sites. In addition to species richness, we analysed mean individual biomass (MIB) and changes in species traits (wing morphology, preferences for particular levels of moisture affinity and temperature) assuming that the percentage of some traits within the community could have changed over the time indicating certain environmental modifications.

In this the first study on carabids over a long period in the Dinaric Alps in Croatia, in addition to changes in carabid assemblages, we checked for a possible displacement of some species along an altitudinal gradient that could point to an increased level of environmental stress due to climate change.

\section{MATERIAL AND METHODS}

\section{Study area}

This study was carried out in the region of the Risnjak mountain massif $(1528 \mathrm{~m})$ located in the Gorski Kotar area in western Croatia, in the northern part of the Dinaric Alps (Fig. 1). Its central part along with the Croatian Snježnik mountain range (1506 $\mathrm{m})$ and the spring of the Kupa River (290 m a.s.l.) are in the Risnjak National Park. The forest communities within the Park are a part of the continuously forested area on the Dinaric Alps in Croatia (Šerić Jelaska \& Durbešić, 2009). This uninhabited woodland on deep karst abounds in geographical, geological and vegetation phenomena (Prugovečki, 1997).

Of the eight sites sampled $\left(\mathrm{L}_{1}-\mathrm{L}_{8}\right)$, three were surveyed in 2015 and $2016\left(\mathrm{~L}_{3}, \mathrm{~L}_{5}, \mathrm{~L}_{8}\right)$ and five additional sites were chosen in 2016. Sites were at altitudes ranging from $704 \mathrm{~m}$ a.s.1. to $1277 \mathrm{~m}$ a.s.l. (Fig. 1, Table 1), with annual rainfall from $1919.3 \mathrm{~mm} \mathrm{yr}^{-1}$ to $3708 \mathrm{~mm} \mathrm{yr}^{-1}$ (values for period between 1990 and 2016), mean maximum annual temperatures from $20.07^{\circ} \mathrm{C}$ to $22.2^{\circ} \mathrm{C}$, and mean minimum annual temperatures from $-7.29^{\circ} \mathrm{C}$ to $-2.34^{\circ} \mathrm{C}$ (values for period between 2006 and 2016).

The forest here is dominated by beech and includes mixed beech-silver fir forests at the lower altitudes and subalpine beech forest at the higher altitudes. Dwarf mountain pine (Pinus mugo) bushes occur at the treeline, above which there are subalpine calcareous grasslands.

The experimental sites $\left(\mathrm{L}_{3}, \mathrm{~L}_{5}, \mathrm{~L}_{8}\right)$ were selected within forest habitats on the upper half of the mountain right up to the top of the tree line. These three sites were at the same location as those used in the research on carabid communities carried out in 1990-1991 (Table 1). Since we did not have information on the exact location of pitfall traps at each location (e.g. geographical coordinates), traps were positioned within forest based on the descriptions of the previous field study. The sampling methods were the same as in 1990-1991.

\section{Sampling protocol}

Ground beetles were sampled between May and October, during 2015 and 2016, using pitfall traps at all eight sites (three sites in 2015 and 2016 plus an additional five sites in 2016). Plastic vessels with a diameter of $9.5 \mathrm{~cm}$ and a depth of $14.0 \mathrm{~cm}(0.5 \mathrm{~L})$ were used as pitfall traps. In 2015 six pitfall traps per site were set (site codes: $\mathrm{L}_{5}, \mathrm{~L}_{6}, \mathrm{~L}_{7}$ ), and in 2016 nine pitfall traps were set at each of the eight sites (site codes: $\mathrm{L}_{1}-\mathrm{L}_{8}$ ). Thus, a total of 90 traps were used during two years. At each site, traps were arranged in two rows with three traps in each row in 2015, and in a grid $(3 \times 3)$ in 2016, with about a 10-meter distance between each trap. The traps were filled up to one-third of their volume with a mixture of ethanol $(96 \%)$, acetic acid $(9 \%)$ and water in equal proportions (as was used in the study in 1990-1991) and reset every two to three weeks continuously throughout the sampling period (2 May 2015-10 Oct. 2015; 12 May 2016-9 Oct. 2016). Pieces of tree bark were placed above the traps to protect them from rain. All specimens were identified to species level (Trautner \& Geigenmüller, 1987; Hůrka, 1996; Freude et al., 2004; Mueller collection in NHM Trieste) and stored either in a 70\% alcohol solution or in a dry state.

\section{Habitat variables}

For each site, we recorded altitude (m a.s.1.), slope (degrees), aspect (i.e. the direction in which a slope faces; calculated as

Table 1. Main features of the sites sampled. The superscript 90/91 means the same site was surveyed in 1990 and 1991.

\begin{tabular}{|c|c|c|c|c|c|c|c|}
\hline \multirow{2}{*}{ Plot } & \multirow{2}{*}{ Plot mark } & \multirow{2}{*}{ Forest type } & \multirow{2}{*}{ Altitude (m a.s.l.) } & \multirow{2}{*}{ Slope } & \multirow{2}{*}{ Aspect } & \multicolumn{2}{|c|}{ Number of traps per year } \\
\hline & & & & & & 2015 & 2016 \\
\hline 1 & $\mathrm{~L}_{1}$ & Dinaric silver fir and beech forest & 704 & 2 & 37.7677 & & 9 \\
\hline 2 & $\mathrm{~L}_{2}$ & Dinaric silver fir and beech forest & 742 & 13 & 80.92365 & & 9 \\
\hline 3 & $\mathrm{~L}_{3}\left(\mathrm{~L}_{3}^{9}{ }^{90 / 91}\right)$ & Dinaric silver fir and beech forest & 727 & 19 & 54.23008 & & 9 \\
\hline 4 & $\mathrm{~L}_{4}$ & Dinaric silver fir and beech forest & 869 & 9 & 350.4352 & & 9 \\
\hline 5 & $\mathrm{~L}_{5}\left(\mathrm{~L}_{5}^{-40 / 91}\right)$ & Dinaric silver fir and beech forest & 1068 & 2 & 30.12193 & 6 & 9 \\
\hline 6 & $\mathrm{~L}_{6}$ & Dinaric silver fir and beech forest & 1160 & 0 & 269.9162 & 6 & 9 \\
\hline 7 & $L_{7}^{6}$ & Subalpine beech forest & 1277 & 16 & 243.5076 & 6 & 9 \\
\hline 8 & $\mathrm{~L}_{8}\left(\mathrm{~L}_{8}{ }^{90 / 91}\right)$ & Subalpine beech forest & 1199 & 4 & 193.4187 & & 9 \\
\hline
\end{tabular}


Table 2. Mann-Kendall test of the trend in maximum and minimum monthly temperatures and total monthly precipitation. *There was a statistically significant increasing trend.

\begin{tabular}{cccc}
\hline \multicolumn{4}{c}{ Mann-Kendall trend test } \\
\hline Delnice & $\mathrm{S}$ & $\mathrm{Z}$ & $\mathrm{P}$ \\
\hline $\mathrm{t}$ max & 284 & 0.42964 & 0.66746 \\
$\mathrm{t}$ min & 947 & 1.4092 & 0.15878 \\
rain & 652 & 0.98812 & 0.32309 \\
\hline Crni Lug & $\mathrm{S}$ & $\mathrm{Z}$ & $\mathrm{P}$ \\
\hline $\mathrm{t}$ max & 294 & 0.44906 & 0.65339 \\
$\mathrm{t}$ min & 955 & 1.7375 & 0.082308 \\
rain & 5044 & 2.451 & $0.014247^{*}$ \\
\hline
\end{tabular}

absolute number of degrees from south), and land cover (forest types: mixed Dinaric silver fir and beech forest, and subalpine beech forest), (Table 1). The first three variables were calculated in a GIS environment, whereas the forest types were identified in the field based on the presence of particular species of plants.

The climate in the study area and how it has changed over the last few decades were analysed based on the data available from the Croatian meteorological and hydrological service (DHMZ). Precipitation data for the whole period (1990-2016) were available for Crni Lug (Risnjak National Park, at cca 800 m a.s.l.) while temperatures in the National Park were not measured before the end of 2003. Therefore, data for the nearest town Delnice (at 700 m a.s.1.) were used (Figs S1, S2). A non-parametric MannKendall test was used to determine trends in the maximum and minimum monthly temperatures and total monthly precipitation (Table 2).

\section{Species traits}

Collected species were grouped with respect to their (1) wing morphology - macropterous (hind wings fully developed), brachypterous (includig apterous; hind wings reduced), and polymorphic (including dimorphic; short-and long-winged forms), (2) moisture preference - hygrophilous, xerophilous, and moistureindifferent species, and (3) temperature preference - thermophilous, mesothermophilous (including eurytherm) and low-temperature (including oligostenotherm) species (Table 3 ).

Traits were compiled from the Carabids.org - online datebase (Homburg et al., 2013) and Vujčić-Karlo (1999), and amended using information from Thiele (1977), Lindroth (1985), Hůrka (1996) and Turin (2000).

Table 3. List of the carabid species recorded at the sites compared, their ecological traits and years when collected. (Wing morphology: $\mathrm{B}$ - brachypterous, $\mathrm{M}$ - macropterous, $\mathrm{P}$ - polypterous, $\mathrm{X}$ - xerophilous, $\mathrm{H}$ - hygrophilous, $\mathrm{M}-$ moisture indifferent, $\mathrm{T}-$ thermophilous, MT - mesothermophilous, LT - low-temperature, NA - no information available.) Sites numbers correspond to those in Table 1. *Author's note: Questionable identification (species from previous papers were not revised as identifications were retrieved as a list from the papers).

\begin{tabular}{|c|c|c|c|c|c|}
\hline Species & $\begin{array}{l}\text { Dispersal } \\
\text { ability }\end{array}$ & $\begin{array}{l}\text { Moisture } \\
\text { preference }\end{array}$ & $\begin{array}{l}\text { Temperature } \\
\text { preference }\end{array}$ & Site & Year \\
\hline $\begin{array}{l}\text { Abax } \\
\text { parallelepipedus }\end{array}$ & B & M & MT & 3 & 2016 \\
\hline Abax carinatus & B & $\mathrm{H}$ & MT & $\begin{array}{l}3 \\
3\end{array}$ & $\begin{array}{c}1990-1991 \\
2016\end{array}$ \\
\hline Abax ovalis & B & $\mathrm{H}$ & MT & \multicolumn{2}{|c|}{$\begin{array}{l}3,5,81990-1991 \\
3,5,8 \text { 2015-2016 }\end{array}$} \\
\hline $\begin{array}{l}\text { Anisodactylus } \\
\text { intermedius }\end{array}$ & M & $\mathrm{H}$ & $\mathrm{T}$ & 3 & 2016 \\
\hline Amara eurynota & $M$ & $\mathrm{x}$ & MT & 3 & 2016 \\
\hline
\end{tabular}

\begin{tabular}{|c|c|c|c|c|}
\hline $\begin{array}{l}\begin{array}{l}\text { Aptinus } \\
\text { bombarda }\end{array} \\
\end{array}$ & $\mathrm{B}$ & M & $\mathrm{T}$ & $\begin{array}{cr}3,8 & 1990-1991 \\
3,5,8 & 2015-2016 \\
\end{array}$ \\
\hline $\begin{array}{l}\text { Calathus } \\
\text { micropterus } \\
\end{array}$ & $\mathrm{B}$ & $x$ & $\mathrm{LT}$ & $5 \quad 1990-1991$ \\
\hline $\begin{array}{l}\text { Calosoma } \\
\text { inquisitor }\end{array}$ & M & $\mathrm{M}$ & MT & $81990-1991$ \\
\hline $\begin{array}{l}\text { Carabus } \\
\text { catenulatus }\end{array}$ & $\mathrm{B}$ & M & MT & $\begin{array}{c}3,5,81990-1991 \\
3,8 \quad 2015-2016\end{array}$ \\
\hline $\begin{array}{l}\text { Carabus } \\
\text { convexus }\end{array}$ & $\mathrm{B}$ & M & $\mathrm{T}$ & $5 \quad 1990-1991$ \\
\hline $\begin{array}{l}\text { Carabus } \\
\text { coriaceus }\end{array}$ & $\mathrm{B}$ & M & MT & $\begin{array}{cc}3,5,8 & 1990-1991 \\
3,8 & 2015-2016 \\
\end{array}$ \\
\hline Carabus creutzeri & $\mathrm{B}$ & $\mathrm{H}$ & $\mathrm{LT}$ & $\begin{array}{ll}8 & 1990-1991 \\
5 & 2015-2016 \\
\end{array}$ \\
\hline $\begin{array}{l}\text { Carabus } \\
\text { croaticus }\end{array}$ & $\mathrm{B}$ & $\mathrm{M}$ & MT & $\begin{array}{l}3,5,81990-1991 \\
3,5,8 \text { 2015-2016 }\end{array}$ \\
\hline $\begin{array}{l}\text { Carabus } \\
\text { violaceus }\end{array}$ & $\mathrm{B}$ & M & $\mathrm{T}$ & $\begin{array}{l}3,5,81990-1991 \\
3,5,82015-2016 \\
\end{array}$ \\
\hline $\begin{array}{l}\text { Cychrus } \\
\text { attenuates }\end{array}$ & $\mathrm{B}$ & $\mathrm{H}$ & $\mathrm{LT}$ & $\begin{array}{l}3,5,81990-1991 \\
3,5,8 \text { 2015-2016 } \\
\end{array}$ \\
\hline $\begin{array}{l}\text { Cymindis } \\
\text { humeralis }\end{array}$ & $\mathrm{P}$ & $\mathrm{H}$ & $\mathrm{LT}$ & $5 \quad 1990-1991$ \\
\hline Harpalus sp.* & $\mathrm{M}$ & NA & NA & $\begin{array}{ll}5 & 1990-1991 \\
5 & 2015-2016 \\
\end{array}$ \\
\hline Leistus nitidus & $\mathrm{P}$ & $\mathrm{H}$ & $\mathrm{LT}$ & $\begin{array}{ll}5 & 2015-2016 \\
\end{array}$ \\
\hline Leistus piceus & $\mathrm{B}$ & $\mathrm{H}$ & MT & 2016 \\
\hline $\begin{array}{l}\text { Leistus } \\
\text { rufomarginatus }\end{array}$ & $\mathrm{P}$ & $\mathrm{H}$ & MT & $\begin{array}{cr}3,5,8 & 1990-1991 \\
8 \quad 2015-2016 \\
\end{array}$ \\
\hline $\begin{array}{l}\text { Leistus } \\
\text { spinibarbis }\end{array}$ & M & $x$ & $\mathrm{~T}$ & $\begin{array}{lc}8 & 1990-1991 \\
3 & 2016\end{array}$ \\
\hline $\begin{array}{l}\text { Licinus } \\
\text { hoffmannseggi }\end{array}$ & $\mathrm{B}$ & $\mathrm{H}$ & $\mathrm{LT}$ & $\begin{array}{cr}5 & 1990-1991 \\
3,5,8 & 2015-2016 \\
\end{array}$ \\
\hline Molops alpestris & $\mathrm{B}$ & $\mathrm{H}$ & MT & $3,5,8$ 1990-1991 \\
\hline Molops elatus & $\mathrm{B}$ & $\mathrm{H}$ & $\mathrm{LT}$ & $5,8 \quad 2015-2016$ \\
\hline Molops ovipennis & $\mathrm{B}$ & M & $\mathrm{LT}$ & $8 \quad 2015-2016$ \\
\hline Molops piceus & $\mathrm{B}$ & $\mathrm{H}$ & $\mathrm{LT}$ & $3,5,82015-2016$ \\
\hline Molops striolatus & $\mathrm{B}$ & M & $\mathrm{T}$ & $\begin{array}{l}3,5,81990-1991 \\
3,5,82015-2016 \\
\end{array}$ \\
\hline Nebria dahlii & $\mathrm{B}$ & $\mathrm{H}$ & $\mathrm{LT}$ & $\begin{array}{l}3,5,81990-1991 \\
3,5,82015-2016 \\
\end{array}$ \\
\hline $\begin{array}{l}\text { Notiophilus } \\
\text { biguttatus }\end{array}$ & $\mathrm{P}$ & $\mathrm{H}$ & MT & $\begin{array}{l}3,5,81990-1991 \\
3,5,2015-2016 \\
\end{array}$ \\
\hline $\begin{array}{l}\text { Platynus } \\
\text { scrobiculatus }\end{array}$ & $\mathrm{B}$ & $\mathrm{H}$ & MT & $\begin{array}{cc}3 & 1990-1991 \\
3 & 2016 \\
\end{array}$ \\
\hline $\begin{array}{l}\text { Pterostichus } \\
\text { burmeisteri }\end{array}$ & $\mathrm{B}$ & M & $\mathrm{LT}$ & $\begin{array}{l}3,5,81990-1991 \\
3,5,82015-2016 \\
\end{array}$ \\
\hline $\begin{array}{l}\text { Pterostichus } \\
\text { fasciatopunctatus }\end{array}$ & $\mathrm{B}$ & $\mathrm{H}$ & $\mathrm{LT}$ & $\begin{array}{lc}3 & 1990-1991 \\
3 & 2016 \\
\end{array}$ \\
\hline $\begin{array}{l}\text { Pterostichus } \\
\text { unctulatus }\end{array}$ & $\mathrm{B}$ & M & $\mathrm{LT}$ & 5,8 1990-1991 \\
\hline $\begin{array}{l}\text { Pterostichus } \\
\text { variolatus }\end{array}$ & $\mathrm{B}$ & M & $\mathrm{LT}$ & $\begin{array}{ll}5,8 & 1990-1991 \\
5,8 & 2015-2016 \\
\end{array}$ \\
\hline $\begin{array}{l}\text { Reicheiodes } \\
\text { rotundipennis }\end{array}$ & $\mathrm{B}$ & $\mathrm{H}$ & LT & 1990 \\
\hline Stomis rostratus & B & $\mathrm{M}$ & MT & $\begin{array}{c}3,5,8 \\
8\end{array}$ \\
\hline Trechus croaticus & B & $\mathrm{H}$ & LT & $3,5,8$ \\
\hline
\end{tabular}

\section{Data analyses}

In this study Margalef's diversity (DMg) and Menhinick's indices (DMn) were calculated as indicators of species richness, Simpsons' index as a dominance index, Shannon-Wiener's (H') as a diversity index and Pielou's (E) as an evenness index (Table 4).

To compare species composition between the sites in all the years sampled (1990, 1991, 2015, 2016), we calculated Jaccard dissimilarity coefficient and grouped the data using Euclidean 
Table 4. Diversity measures recorded at the sites studied. The site codes marks correspond to those used in Table 1.

\begin{tabular}{|c|c|c|c|c|c|c|c|c|c|c|c|}
\hline Site & $\mathrm{L}_{1}$ & $\mathrm{~L}_{2}$ & $\mathrm{~L}_{3}$ & $\left(\mathrm{~L}_{3}{ }^{90 / 91}\right)$ & $\mathrm{L}_{4}$ & $\mathrm{~L}_{5}$ & $\left(L_{5}{ }^{90 / 91}\right)$ & $\mathrm{L}_{6}$ & $\mathrm{~L}_{7}$ & $\mathrm{~L}_{8}$ & $\left(\mathrm{~L}_{8}{ }^{90 / 91}\right)$ \\
\hline Total species (S) & 16 & 16 & 21 & 18 & 15 & 16 & 22 & 15 & 14 & 17 & 20 \\
\hline Total carabids collected $(\mathrm{N})$ & 696 & 469 & 581 & 659 & 543 & 1894 & 4985 & 2973 & 730 & 1635 & 8688 \\
\hline Total carabids collected per day per trap $(\mathrm{Nd})$ & 0.573 & 0.386 & 0.478 & 0.107 & 0.447 & 0.449 & 0.807 & 0.705 & 0.173 & 1.346 & 1.406 \\
\hline Margalef's diversity index $(\mathrm{DMg}) D M g=(S-1) / \ln (\mathrm{Nd})$ & -26.92 & -15.76 & -27.11 & -7.59 & -17.38 & -18.75 & -97.73 & -40.11 & -7.41 & 53.89 & 55.78 \\
\hline Menhinick's diversity index (DMn) $D M n=S / \sqrt{N d}$ & 21.14 & 25.75 & 30.37 & 55.12 & 22.44 & 23.87 & 24.49 & 17.86 & 33.64 & 14.65 & 16.86 \\
\hline Simpsons' index (D) $D=\sum p_{i}^{2}$ & 0.43 & 0.16 & 0.25 & 0.23 & 0.15 & 0.64 & $0 ., 23$ & 0.40 & 0.14 & 0.51 & 0.41 \\
\hline Shannon Wiener index $\left(\mathrm{H}^{\prime}\right) H^{\prime}=-\sum p_{i} \ln p_{i}$ & 1.38 & 2.04 & 1.84 & 1.91 & 2.09 & 0.95 & 1.85 & 1.29 & 2.11 & 1.15 & 1.30 \\
\hline Pielou's evenness (E) $E=H / \ln (S)$ & 0.49 & 0.74 & 0.60 & 0.66 & 0.78 & 0.34 & 0.60 & 0.47 & 0.80 & 0.41 & 0.43 \\
\hline
\end{tabular}

distance as distance measure and complete linkage as linkage rule for constructing dendrograms (Krebs, 1989), (Fig. 2). ShapiroWilk and Levene's tests were used to check for normal distribution of data and homogeneity of variance. In addition, nonparametric Kruskal Wallis one-way ANOVA and Mann-Whitney $\mathrm{U}$ tests were used. Since there were no significant differences in species composition and abundance among years (except for site $\mathrm{L}_{3}$ in 1991 and 2016), we pooled data for 1990 and 1991 in one group and data for 2015 and 2016 in another group for further trait analyses.

Similarities in species composition according to the percentages of tested species traits (wing morphology, moisture and temperature affinity) recorded at the same sites in 1990-1991 and resampled in 2015-2016 were evaluated using repeated measures or one-way ANOVA. Principal Components Analysis (PCA) was used to explore variation in the distribution of the species traits among all sites. Pearson's correlation coefficient was used to measure the strength of the linear relationship between the percentages of the species traits with altitude. Multivariate linear regression analyses were used to determine the altitudinal distribution of the observed species traits.

Mean individual biomass (MIB) was calculated using a formula that describes the relationship between body length and live biomass of a carabid beetle: $\ln y=-8.928+2.555 \times \ln x$ (Szyszko, 1983). Data on the body length of the species caught were obtained from the Carabids.org - online datebase (Homburg et al., 2013). Differences in carabid biomass were standardise per trap per day for both of the periods 1990-1991 and 2015-2016, before further analyses.

Rarefaction curves were estimated for three of the sites in 1990-1991 and all of the sites in 2015-2016 (Fig. 3A, B).

The IBM SPSS v21; EstimateS v9.1. and Past 3 program packages were used for statistical calculations.

\section{RESULTS}

A total of 9, 521 individual ground beetles belonging to 17 genera and 33 species were collected during the two years, 2015-2016 (Table S1). The first five most abundant carabid species were brachypterous and made $>80 \%$ of all the carabids captured (Nebria dahlii 42.43\%, Aptinus bombarda 17.14\%, Pterostichus burmeisteri 9.7\%, Pterostichus variolatus $8.22 \%$ and Abax ovalis $6.1 \%$ ). The number of species per site varied from 9 (site $\mathrm{L}_{6}$ in 2015) to 21 (site $\mathrm{L}_{3}$ in 2016). Species found at all of the sites were: Abax ovalis, Carabus violaceus, Cychrus attenuatus, Molops striolatus, Nebria dahlii and Pterostichus burmeisteri.

\section{Changes in ground beetle assemblages 1990-2016}

A total of 40 species were caught in 1990-1991 and 2015-2016 (sites $\mathrm{L}_{3}, \mathrm{~L}_{5}$ and $\mathrm{L}_{8}$ ), of which only 7 species
(Calathus micropterus, Calosoma inquisitor, Cymindis humeralis, Reicheiodes rotundipennis, Molops alpestris, Pterostichus unctulatus and Trechus croaticus) were caught in 1990-1991 and 10 species (Abax parallelepipedus, Anisodactylus intermedius, Amara eurynota, Leistus nitidus, Leistus piceus, Loricera pilicornis, Molops elatus, Molops ovipennis, Molops piceus, and Nebria brevicollis) in 2015-2016, which indicated that the fauna recorded in 2015-2016 was richer. Species found at all of the sites in 1990-1991 and 2015-2016 were: Abax ovalis, Carabus violaceus, Cychrus attenuatus, Molops striolatus, Nebria dahlii and Pterostichus burmeisteri.

Analysing the composition and abundance of species in different years and sites, a statistically significant difference was recorded between 1991 and 2016 for site $\mathrm{L}_{3}$ (Shapiro-Wilk W: 0.2595, Levene's test for homogeneity of variance $p<0.01$, Kruskal-Wallis $p=0.2799$, MannWithney pairwise, $p=0.009$ ), while in other years and sites they did not differ significantly. The activity density (the total number of trapped specimens) of the most abundant species in 1990-1991 was for Nebria dahlii, which made up $48.99 \%$ of all the carabids caught. Based on their abundance the following species: Pterostichus variolatus (14.12\%), Pterostichus unctulatus (11.97\%), Pterostichus burmeisteri (6.58\%) and Abax ovalis (6.38\%), made up $88.04 \%$ of all the carabids caught.

In 2015-2016 the top five of the most numerous species (sites $\mathrm{L}_{3}, \mathrm{~L}_{5}$ and $\mathrm{L}_{8}$ ) were: Nebria dahlii (41.68\%), Aptinus bombarda (34.09\%), Pterostichus burmeisteri (8.2\%),

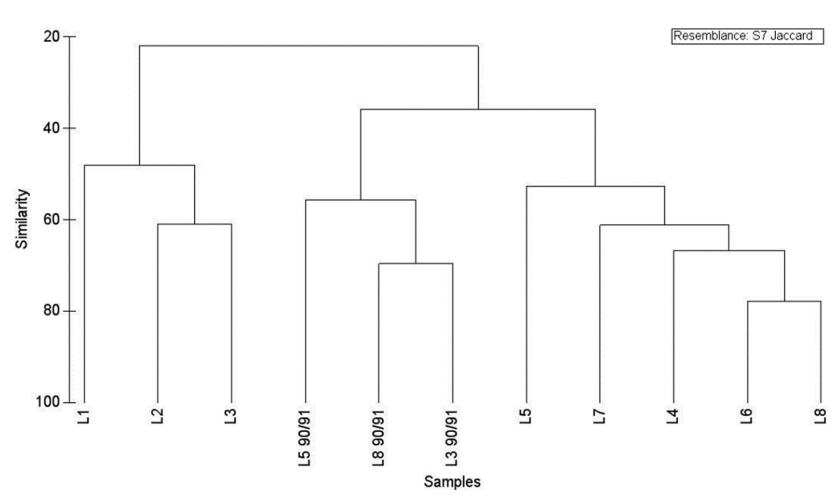

Fig. 2. Tree diagram of cluster analyses using Jaccard dissimilarity coefficient to measure similarity. The marks on the $x$-axes denote the sites investigated and correspond to those in Table 1. 

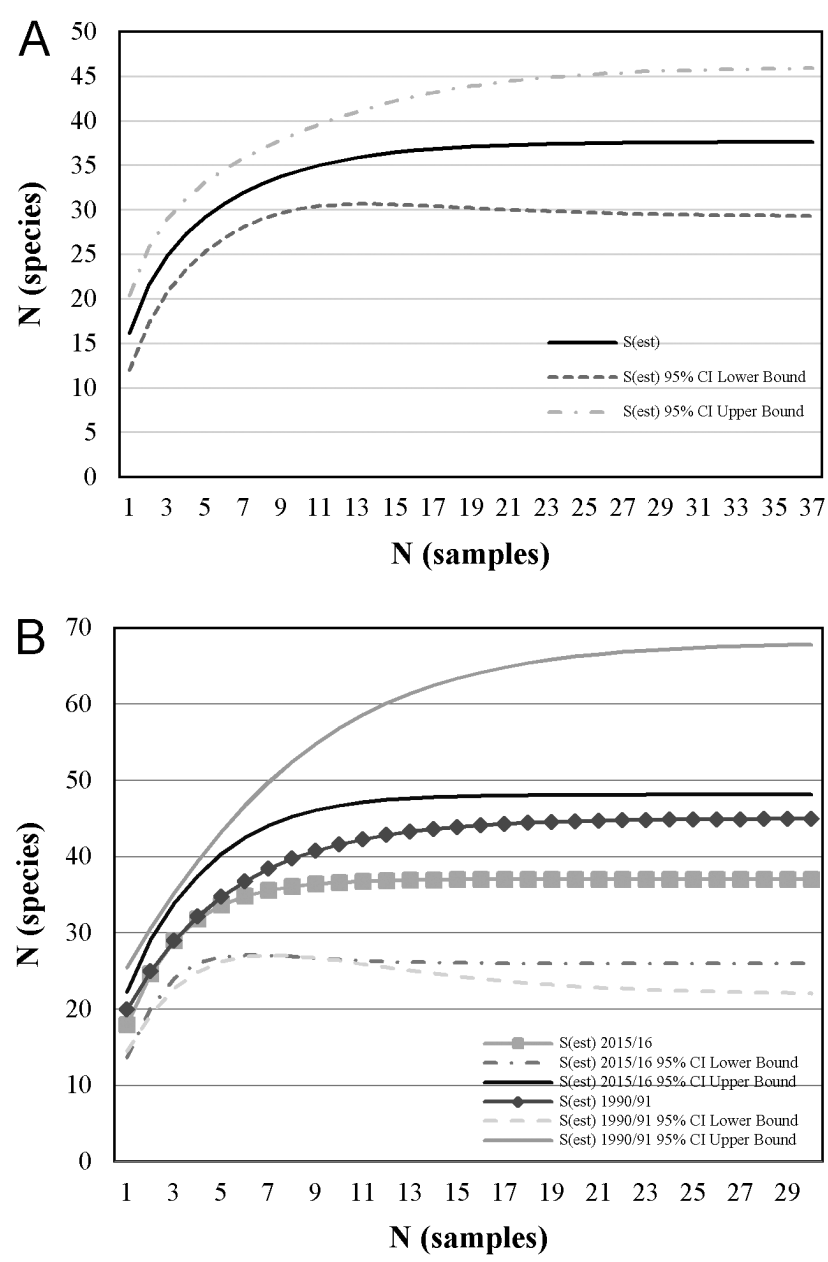

Fig. 3. $A$ - Rarefaction curves obtained for the eight sites $\left(L_{1}-L_{8}\right)$ studied in 2015-2016. B - Rarefaction curves obtained for the three sites $\left(L_{3}, L_{5}, L_{8}\right)$ studied in 1990-1991 and again in 2015-2016.

Carabus violaceus (2.8\%) and Abax ovalis (2.77\%), which together made up $89.54 \%$ of all the carabids caught.

Of the common species caught in both periods, the biggest increase in the number caught was recorded for Aptinus bombarda, which increased from $0.27 \%$ in $1990-1991$ to $34.09 \%$ of all carabids caught in 2015-2016 and Pterostichus fasciatopunctatus from $0.007 \%$ in $1990-1991$ to $0.46 \%$ in $2015-2016$. The highest decreases in the number of individuals caught was recorded for Leistus rufomarginatus from $1.86 \%$ in $1990-1991$ to $0.024 \%$ in $2015-2016$, and Stomis rostratus from $0.32 \%$ in $1990-1991$ to $0.024 \%$ in 2015-2016. A decrease was also recorded in the number of endemic species like Pterostichus variolatus, from $14.12 \%$ in $1990-1991$ to $2.31 \%$ in $2015-2016$ at the three sites that were compared.

Endemics like Molops alpestris, Pterostichus unctulatus and Trechus croaticus were not caught in 2015-2016.

Comparing each of the three sites that were sampled in 1990-1991 and again in 2015-2016 all of the diversity indices (except DMg for site $\mathrm{L}_{5}$ ) indicate that the diversity was higher in 1990-1991 than in 2015-2016 (Table 4), and based on species composition using Jaccard similarity index the sites sampled in 1990-1991 $\left(\mathrm{L}_{3}, \mathrm{~L}_{5}, \mathrm{~L}_{8}\right)$ formed one cluster and those sampled in 2015 and $2016\left(\mathrm{~L}_{1}-\mathrm{L}_{8}\right)$ another cluster (Fig. 2).

\section{Species trait analyses of the assemblages recorded between 1990-2016 along an altitudinal gradient}

The analyses of variance (repeated measures ANOVA) did not reveal statistically significant differences in carabid assemblages based on wing morphology in the two periods compared (1990-1991 and 2015-2016). Because of the zero variance between some sites, the difference in moisture preference in the two periods sampled could not be tested using factorial ANOVA. Instead, one-way ANOVA was used and did not reveal a statistically significant differences $[F(1,13)=0.29, p=0.5946]$, but some trends were recorded. The most numerous species, in both periods, were brachypterous and hygrophilous or moisture indifferent. Differences were recorded in temperature preference; in 1990-1991 the first four of the most numerous species were low-temperature species $(N$. dahlii, $P$. variolatus, $P$. unctulatus, $P$. burmeisteri) while in 2015-2016 two of the four the most numerous species (N. dahlii, A. bombarda, $P$. burmeisteri, $C$. violaceus) were thermophilous, including the second most abundant.

\section{Site $L_{3}$ in 1990-1991 and 2016}

Based on the ecological traits of the different species, three macropterous species of which two were xerophilic (Anisodactylus intermedius, Amara eurynota, Leistus spinibarbis) were caught in 2015-2016, whereas in 1990-1991 no macropterous or xerophilic species were caught (Table $3)$.

A big increase in the abundance of Aptinus bombarda was recorded, from $4.71 \%$ in $1990-1991$ to $43.72 \%$ in 2016, which is an increase of 42 times more specimens caught per day.

\section{Site $L_{5}$ in 1990-1991 and 2015-2016}

In 2015-2016, among the top five most numerous carabids caught there were two thermophilous species (Carabus violaceus, Molops striolatus), whereas in 1990-1991 only low-temperature species were dominant (Pterostichus unctulatus, Nebria dahlii, Pterostichus variolatus, Pterostichus burmeisteri), (Table 3).

\section{Site $L_{8}$ in $1990-1991$ and 2016}

In 1990-1991 the top five most numerous species were low-temperature species whereas in 2016 the most numerous species was thermophilous (Aptinus bombarda), (Table 3). In addition, the endemic species Pterostichus variolatus decreased in abundance from $18.06 \%$ to $1.7 \%$ between 1990-1991 and 2016.

A high positive correlation between the percentage of low-temperature species and increase in altitude was recorded $(r=0.76)$. Pearson's correlation coefficients also showed a positive correlation between large $(r=0.54)$, brachypterous $(r=0.33)$ and moisture-indifferent species $(r=0.47)$ with increase in altitude, indicating that large, brachypterous, low-temperature and moisture-indifferent species are more likely to occur at high altitudes. 


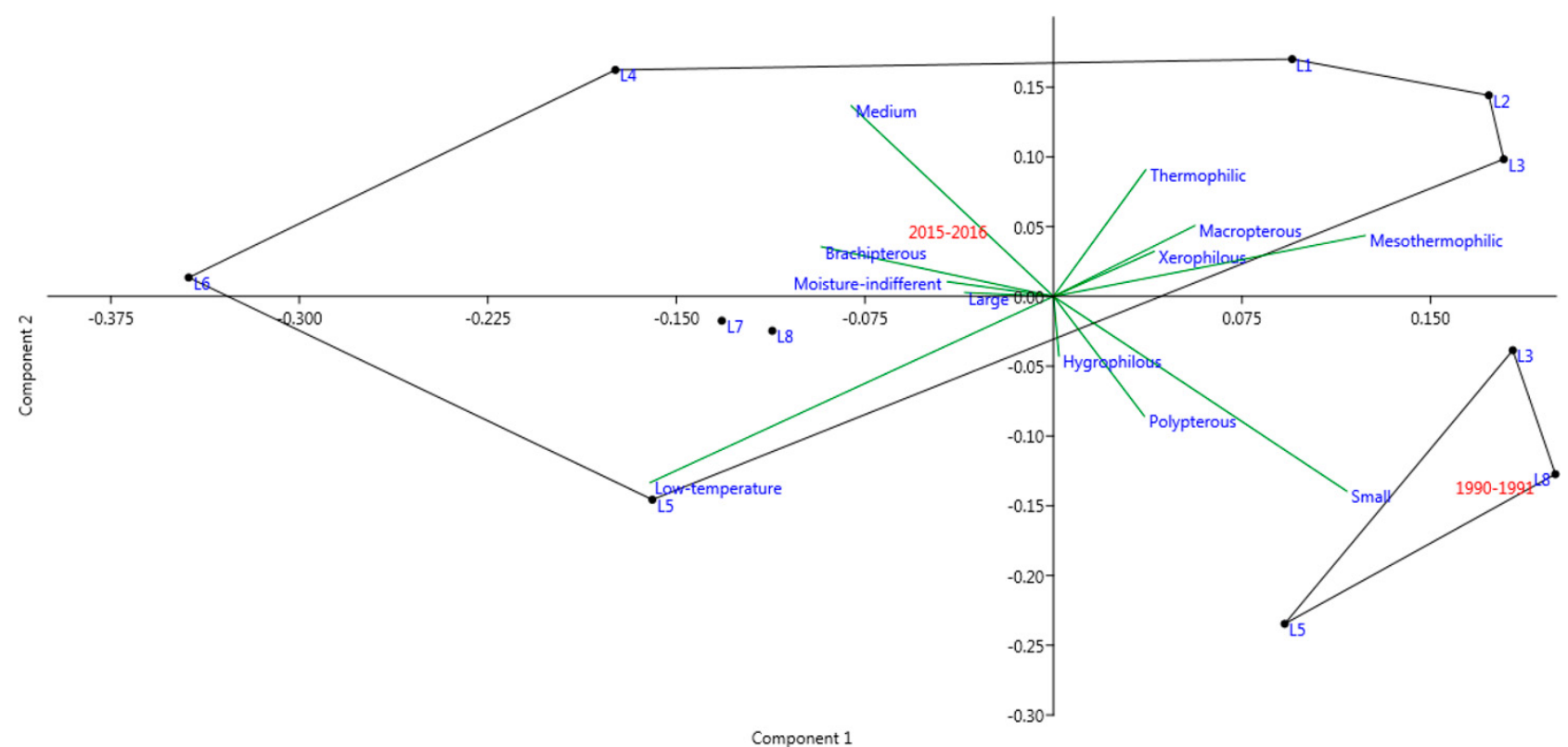

Fig. 4. A PCA correlation tri-plot showing the variation in the distribution of the species traits among sites $\left(L_{1}-L_{8}\right.$ sampled in $2015-2016$ and $L_{3}, L_{5}$ and $L_{8}$ sampled in 1990-1991).

The first two axes of the PCA graph (Fig. 4) represent $66.95 \%$ of the total variance $(44.44 \%$ and $22.5 \%$, respectively). The first axis separates sites $\mathrm{L}_{1}, \mathrm{~L}_{2}$ and $\mathrm{L}_{3}$ (sampled in 2015 and 2016) at low altitudes on the right side of the ordination space based on their higher percentage of thermophilic, xerophilic and macropterous species, and sites sampled in 1990 and $1991\left(\mathrm{~L}_{3}, \mathrm{~L}_{5}, \mathrm{~L}_{8}\right)$ with smaller and polypterous species. On the left side of the ordination biplot, there are the sites $\mathrm{L}_{4}, \mathrm{~L}_{5}, \mathrm{~L}_{6}, \mathrm{~L}_{7}$ and $\mathrm{L}_{8}$ (sampled in 2015 and 2016) at high altitudes, with a high percentage of low-temperature, moisture-indifferent and large brachypterous species. Along the second ordination axis, there are sites $\mathrm{L}_{5}$ and $\mathrm{L}_{8}$ (sampled both in 1990-1991 and 2015-2016) that are separated on the basis of their higher percentage of low-temperature species from those sampled in 1990-1991 with more polypterous and smaller species.

Distribution of the traits analysed (Fig. 5) along the altitudinal gradient revealed some general trends in terms of brachypterous, large, cold-adapted species being more abundant at high altitudes.

Analysing mean individual biomass recorded at the sites that were compared revealed a statistically significant difference for site $\mathrm{L}_{3}\left(\mathrm{MIB}^{1990-1991}=0.0178\right.$; $\mathrm{MIB}^{2016}=0.0843$; $\mathrm{p}=0.04)$ with a markedly higher biomass of Aptinus bombarda, Carabus coriaceus and Carabus violaceus in 20152016 than in 1990-1991. The remaining two sites $\left(\mathrm{L}_{5}, \mathrm{~L}_{8}\right)$ differed slightly in their MIB values. $\left(\mathrm{L}_{5}: \mathrm{p}=0.46 ; \mathrm{L}_{8}: \mathrm{p}=\right.$ 0.97 ) with lower biomass of the endemic mountain species Pterostichus variolatus in 2015-2016 than in 1990-1991.

Based on the percentage of different species at given altitudes we noticed a possible displacement of some species along the altitudinal gradient (Fig. 6). Notiophilus biguttatus, a mesothermophilous and hygrophilous species whose altitudinal range in 1990-1991 was from $742 \mathrm{~m}$ to 1199 $\mathrm{m}$, in 2015-2016 was not recorded above $1068 \mathrm{~m}$; Licinus hoffmannseggi, a low-temperature and hygrophilous species, in 2015-2016 seemed to expand its range at both low and high altitudes (from $742 \mathrm{~m}$ to $1277 \mathrm{~m}$ ) recorded in 1990-1991, but at only one site $\mathrm{L}_{6}(1060 \mathrm{~m})$; Stomis rostratus, a mesothermophilous and moisture indifferent species, seemed to reduce its range in 2015-2016 and was caught only at site $\mathrm{L}_{8}(1199 \mathrm{~m})$ while 25 years ago it was recorded at altitudes from $742 \mathrm{~m}$ to $1199 \mathrm{~m}$ (sites $\mathrm{L}_{3}, \mathrm{~L}_{5}$, $\mathrm{L}_{8}$ ). The expected increase in abundance of cold-adapted endemic species with altitude was recorded for the species C. creutzeri and P. variolatus. Both these species were recorded at altitudes from $1068 \mathrm{~m}$ to $1277 \mathrm{~m}$ and were the most numerous at the highest site $\left(\mathrm{L}_{7}, 1277 \mathrm{~m}\right)$. This was also recorded for another endemic mesothermophilous species, C. croaticus. It was recorded at altitudes from 742 $\mathrm{m}$ to $1277 \mathrm{~m}$ and was by far the most numerous ( $20 \%$ of the total catch) at the highest site $\left(\mathrm{L}_{7}\right)$.

The 25-years moving average of minimum and maximum monthly temperatures and mean total rainfall (Figs S1, S2) did not differ significantly (independent samples T-test: Risnjak - Crni Lug rainfall: $\mathrm{t}(46)=-1.157 ; \mathrm{p}=$ 0.253; Delnice Tmax: $t(41)=-0.933 ; p=0.357$; Delnice Tmin: $\mathrm{t}(41)=-0.135 ; \mathrm{p}=0.894)$. However, results of a non-parametric Mann-Kendall test revealed a statistically significant increasing trend with time in monthly precipitation (Table 2).

\section{DISCUSSION}

Analysing the species composition of carabids assemblages and distribution of species traits between communities sampled at the same sites in 1990-1991 and again 25 

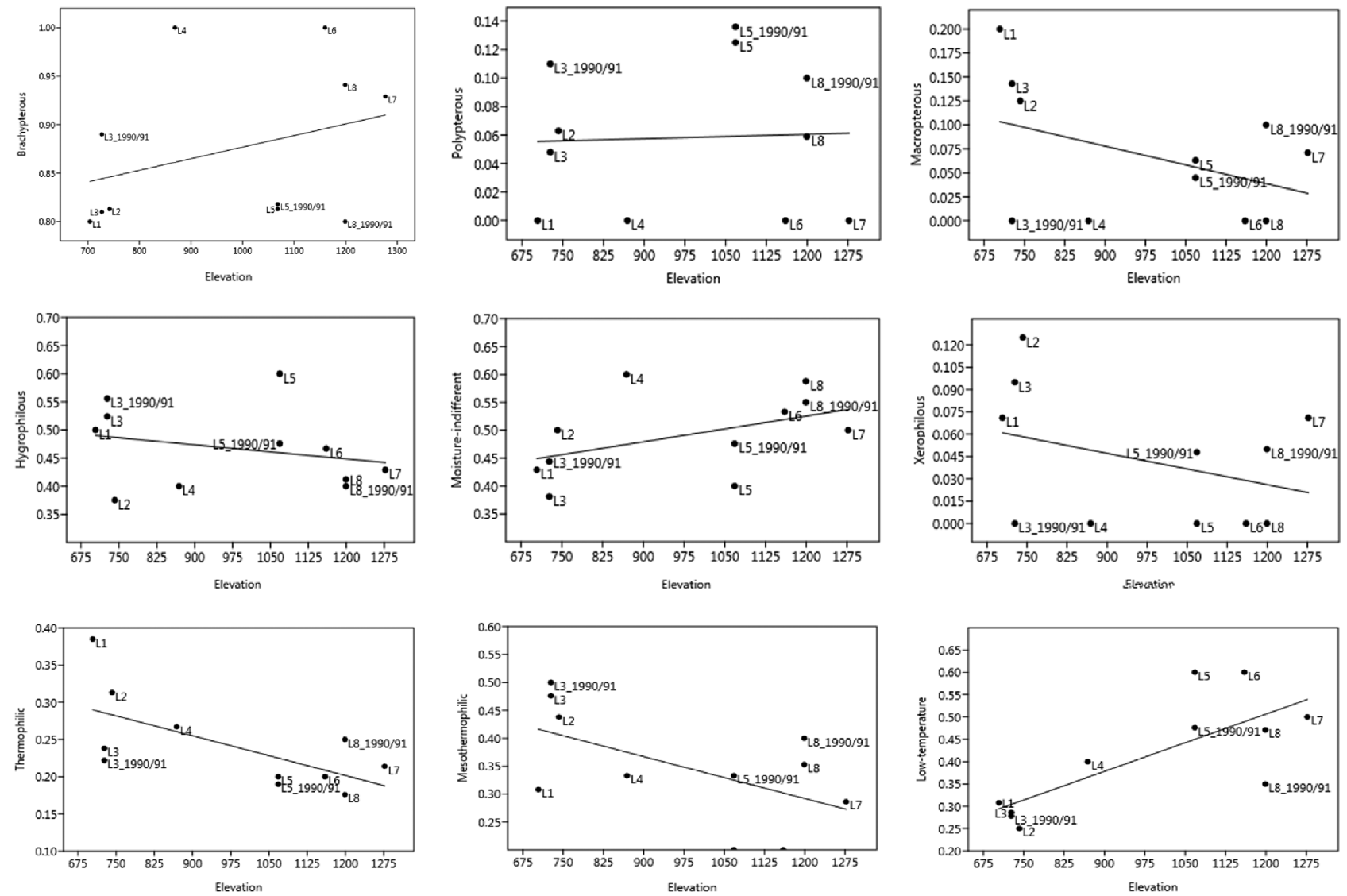

Fig. 5. Multivariate linear regression analysis of the relationship between species traits $(y)$ and altitude $(x)$ for each site.

$\%$ relative abundance

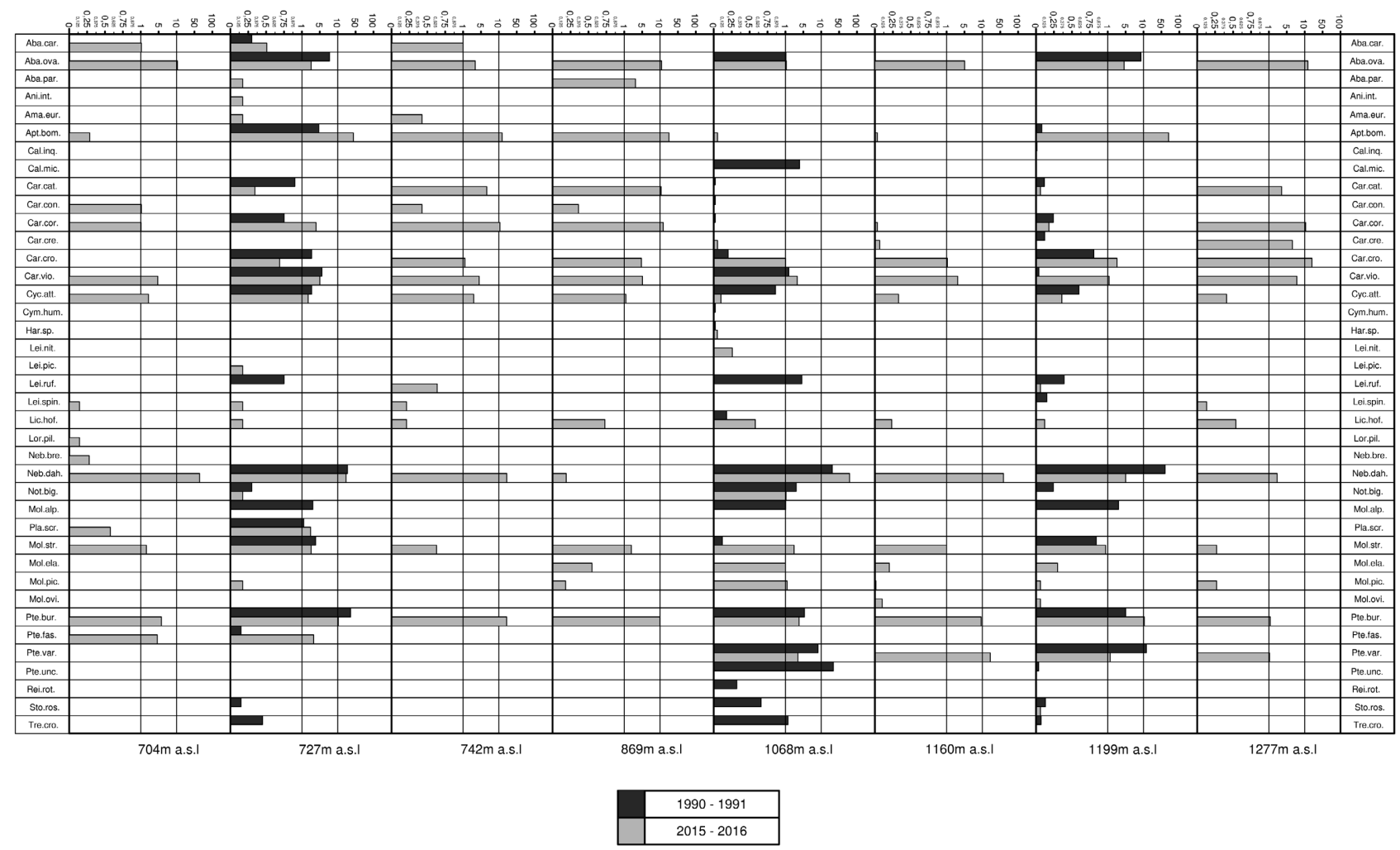

Fig. 6. Distribution and \% relative abundance of species sampled in 1990-1991 (site $L_{3}, L_{5}, L_{8}$ ) and in 2015-2016 (site $L_{1}-L_{8}$ ). Altitudes correspond to the sites as in Table 1, and abbreviations of carabid names correspond to those in Table S1. 
years later, we revealed an increase in the number of thermophilous species and decrease in the number of species preferring low temperatures at some of the sites, among them some mountain specialists (e.g. P. unctulatus) and species typical of the Alpine-Dinaric region (e.g. P. variolatus). This is an expected consequence of global warming and supported by the fact that there was a slight increase in the minimum temperature recorded on Mt. Risnjak and in the Gorski Kotar region over the last 25 years (Crni Lug: $\mathrm{m}=0.61$; Delnice: $\mathrm{m}=0.26$ ). The most obvious changes were recorded at site $\mathrm{L}_{8}$, which is located in a subalpine beech forest, where in 1990-1991, more than $60 \%$ of the total catch consisted of species prefering low-temperatures and high humidity, such as Nebria dahlii, while the most numerous species at the same site 25 years later was Aptinus bombarda (70.1\% of the total catch), which is a thermophilous and mesohigrophilic species. In addition, a big decrease in the low-temperature prefering species Pterostichus variolatus was also recorded at this site (an 11 fold decrease in the number of specimens caught per day). The lack of the mountain specialist, Pterostichus unctulatus, in the catches in 2015-2016 and the fact that this species made almost $12 \%$ of the total catch in 1990-1991 also indicate a decline in the abundance of low-temperature preferring species in this protected area. A similar decreasing trend in the abundance of low-temperature preferring species is recorded in long term studies in the Alps (Pizzoloto et al., 2014) and High Tatra Mts, where in 2004 after a windstorm, at some sites, less tolerant species, including $P$. unctulatus, disappeared (Šustek, 2013).

Certain changes can be associated with ice storms, which are characterized by freezing rain, which in February 2014 destroyed more than $680,000 \mathrm{~m}^{3}$ of timber in the National Park (Editorial Board Šumarski list, 2014). This natural disturbance and the removal of some of the damaged trees could have stressed some parts of the ecosystem. Thinning of the forest and changes in primary habitats might account for the increase in the number of thermophilous species given that there were no significant changes in the climate in this area. But the existence of only one climatological station in the National Park is insufficient for precise monitoring of microclimatic changes in this area.

One of the most important morphological traits of carabids used for bioindication purpose, wing morphology, clearly defines the ecology and evolution occuring in a certain area (Darlington, 1943; Wagner \& Liebherr, 1992). Defining the percentage of species of carabids that are wingless has proved to be a powerful method for determining the stability of an area (Dhuyvetter et al., 2007; Wagner \& Liebherr, 1992; Szyszko et al., 2000; Gobbi et al., 2007; Šerić Jelaska \& Durbešić, 2009; Pizzolotto et al., 2016). Therefore, we used it to compare the sites sampled in 1990-1991 and again 25 years later. The high abundance and percentage of brachypterous species $(62.5 \%$ of the species, $99.5 \%$ of the individuals) caught in 2015-2016 and the absence of differences in wing morphology recorded at these three sites then and in 1990-1991 (brachypterous species: $1990-1991$ : $79.3 \%$ of the species, $96.8 \%$ of the individuals; $2015-2016: 75.9 \%$ of the species, $99.2 \%$ of the individuals) may indicate that the forest ecosystems in the National Park in general are stable.

Risnjak National Park as a part of the Dinaric Mountains chain has many endemic species some of which were recorded in this study (N. dahlii, C. catenulatus, C. croaticus, C. creutzeri, M. ovipennis, P. unctulatus, P. variolatus, $S$. rostratus). Most of them are mountain habitat specialists and low-temperature preferring species. Although some species may benefit from increases in availability of habitats by moving to higher altitudes, the Dinarides are socalled "mountain pyramids" on which there is a decrease in the availability of habitats with increase in altitude (Elsen \& Tingley, 2015). Ultimately this can cause the local extinction of affected species (Colwell et al., 2008; Sekercioglu et al., 2008, 2012; La Sorte \& Jetz, 2010).

The displacement of low-temperature species to higher and lower altitudes and that of mesothermophilous species may be due not only to extrinsic characteristics that affect the displacements' paths of certain species, but also species' intrinsic characteristics on which the response to environmental disturbances depends (Nolte et al., 2019).

It is expected that most endemic high mountain coldadapted specialist will tend to move upwards with increase in the average annual temperature (Wilson et al., 2005; Pizzoloto et al., 2014; Scalercio et al., 2014). Although we do not have enough data to verify a possible change in temperature over the last 25 years, we noticed that two endemic low temperature species (C. creutzeri, P. variolatus) and one endemic mesothermophilous species (C. croaticus) are now the most numerous at the site located at the highest altitude.

According to Nolte et al. (2019), mountain habitat species are at greater risk of extinction than forest species. Thus, vegetation cover may have a mitigating role and maybe extend the time species have to adapt to new conditions. Consequently, any destruction of forest ecosystems, either by man (thinning) or indirectly by unpredictable weather conditions due to climate change, will impair habitat quality and diminishes its protective role in species conservation. Species at greatest risk of extinction include specialist predatory species, those with latitudinal and altitudinal restrictions and brachypterous species (Feehan et al., 2009). Due to stenovalence and inability to cope with sudden landscape changes (Gaston \& Fuller, 2009) specialists are considered to be the most vulnerable at times of evident climate change (Kotze \& O'Hara, 2003; Terzopoulou et al., 2015).

Penev (1996) points out that the composition of carabid assemblages is one of the most revealing ways of detecting changes in ecosystems. It contributes to the discovery of the effects of climate change and indicates the importance of regular and long-term monitoring (Kerr et al., 2007; Vaibhao et al., 2013). Current methods of monitoring insects assemblages require a lot of effort, so it is not surprising that there is only a small number of such long-term studies (Shortall et al., 2009; Fuentes-Montemayor et al., 2011; Dirzo et al., 2014). This is unfortunate as it makes it dif- 
ficult to study the changes occurring in insect assemblages with changes in the environment. This is the case in the Risnjak National Park, which represents a natural link between the Alps and the Balkans and the most significant example of the separation of Croatia (np-risnjak.hr). The first extensive research in the field in this National Park was carried out in 1963-1964 (Durbešić, 1967) at six sites, then almost 27 years later at four different sites (VujčićKarlo, 1999) and then this study at eight sites.

Prediction of species-specific responses to new circumstances isn't possible without intensive and regular monitoring of carabid assemblages, especially bearing in mind the increase in anthropogenic influences and unpredictable weather conditions as a consequence of climate change. The protection of an area without further monitoring doesn't mean much in terms of protecting high mountain endemic species as they have already suffered to some extent the consequences of quick climatic changes as mountain ecosystems are among the first to suffer the consequence of global warming. Thus, despite the study of protected forests within the National Park, there was a decrease in the number of specialist species and the spread of generalist species. The necessity for continuous monitoring, in the current period of obvious climate change, is becoming unquestionable (Saunders, 2017). The high number of endemic and threatened species in mountain ecosystems such as the Dinarides requires monitoring as it is the only way to recognise and mitigate changes that can lead to the reduction of biodiversity and permanent loss of some endemic species.

ACKNOWLEDGEMENTS. This research was financially supported by Croatian Ecological Society (HED); project No. 4492/16. We would like to thank L. Vladić and A. Jakovac for their assistance with fieldwork. We are also immensely grateful to P. Brandmayr for helping with species traits as well as T. van Gijzen for the identification of some species. Many thanks to S.D. Jelaska for helpful comments on an earlier draft of the paper, the determination of vegetation cover, and for help in constructing Fig. 1 based on GIS data. We wish to thank the staff of the Risnjak National Park for their hospitality during our fieldwork and two reviewers for their valuable comments on the manuscript.

\section{REFERENCES}

Blaszkiewicz M. \& Schwerk A. 2013: Carabid beetle (Coleoptera: Carabidae) diversity in agricultural and post-agricultural areas in relation to the surrounding habitats. - Baltic J. Coleopt. 13: 15-26.

Bradley J.C., Duffy E.J., Gonzales A., Hooper D.U., Perrings C., Venail P., Narwani A., Mace G.M., Tilman D., Wardle D.A. ET AL. 2012: Biodiversity loss and its impact on humanity. - Nature 486: 59-67.

Brambilla M. \& GobBi M. 2013: A century of chasing the ice: delayed colonisation of ice-free sites by ground beetles along glacier forelands in the Alps. - Ecography 37: 33-42.

Brandmayr P., Giorgi F., Casale A., Colombetta G., Mariotti L., Vigna Taglianti A., Weber F. \& Pizzolotto R. 2013: Hypogean carabid beetles as indicators of global warming? - Environ. Res. Lett. 8: 044047, 11 pp.

BrigGs J.C. 2017: Emergence of a sixth mass extinction? - Biol. J. Linn. Soc. 122: 243-248.
Ceballos G., Ehrlich. P.R., Barnosky A.D., García A., Pringle R.M. \& PALMER T.M. 2015: Accelerated modern human-induced species losses: entering the sixth mass extinction. - Science Adv. 1: e1400253-e1400253.

Colwell R.K., Brehm G., Cardelus C.L., Gilman A.C. \& LongINO J.T. 2008: Global warming, elevational range shifts, and lowland biotic attrition in the wet tropics. - Science 322: 258-261.

DARLINGTON P.J. 1943: Carabidae of mountains and islands: data on the evolution of isolated faunas, and on atrophy of wings. Ecol. Monogr. 13: 37-61.

Desender K., Dufrene M., Loreau M., Luff M.L. \& Maelfait J.P. 1994 (eds): Carabid Beetles: Ecology and Evolution. Kluwer, Dordrecht, $474 \mathrm{pp}$.

Dhuyvetter H., Hendrickx F., Gaublomme E. \& Desender K. 2007: Differentiation between two salt marsh beetle ecotypes: evidence for ongoing speciation. - Evolution 61: 184-193.

Dirzo R., Young H.S., Galetti M., Ceballos G., Isaac N.J. \& Collen B. 2014: Defaunation in the Anthropocene. - Science 6195: 401-406.

DuRBEŠIĆ P. 1967: Contribution to Entomofauna Blattoidea, Orthopteroidea, Dermapteroidea and Coleopteroidea of the Croatian Coast, Lika and Gorski Kotar in Relation to the Composition of Fitocenosis. MSc thesis, Faculty of Science, University of Zagreb, 83 pp. [in Croatian].

EDITORIAl BoARd 2014: Editorial. Freezing rain in Gorski Kotar. — Šumarski List 138: 6.

Elsen P.R. \& Tingley M.W. 2015: Global mountain topography and the fate of montane species under climate change. - Nature Climate Change 5: 772-776.

Eyre M., LotT D.A. \& Garside A. 1996: Assessing the potential for environmental monitoring using ground beetles (Coleoptera: Carabidae) with riverside and Scottish data. - Ann. Zool. Fenn. 33: 157-163.

Feehan J., Harley M. \& van Minnen J. 2009: Climate change in Europe. 1. Impact on terrestrial ecosystems and biodiversity. A review. - Agron. Sustain. Dev. 29: 409-421.

Freude H., Harde K.-W., Lohse G.A. \& Klausnitzer B. 2004: Die Käfer Mitteleuropas. Band 2. Adephaga. 1. Carabidae (Laufkäfer). Elsevier, Spektrum, Heidelberg, 521 pp.

Fuentes-Montemayor F., Goulson D. \& Park K. 2011: The effectiveness of agri-environment schemes for the conservation of farmland moths: Assessing the importance of a landscapescale management approach. - J. Appl. Ecol. 48: 532-542.

GASTON K.J. \& FulLER R.A. 2009: The sizes of species' geographic ranges. - J. Appl. Ecol. 46: 1-9.

Gobbi M., Rossaro B, Vater A., De Bernardi F., Pelfini M. \& BRANDMAYER P. 2007: Environmental features influencing Carabid beetle (Coleoptera) assemblages along a recently deglaciated area in the Alpine region. - Ecol. Entomol. 32: 682-689.

Gobbi M., Caccianiga M., Cerabolini B., Bernardi F., Luzzaro A. \& Pierce S. 2010: Plant adaptive responses during primary succession are associated with functional adaptations in ground beetles on deglaciated terrain. - Commun. Ecol. 11: 223-231.

Gobbi M., Isaia M. \& De Bernardi F. 2011: Arthropod colonisation of a debris-covered glacier. - Holocene 21: 343-349.

Grum L. 1986: Density fluctuations in a carabid guild. In Den Boer P.J., Luff M.L., Mossakowski D. \& Weber F. (eds): Carabid Beetles: Their Adaptations and Dynamics. Proc. XVII International Congress of Entomology. Gustav Fischer, Stuttgart, pp. 343-359.

Harte J., Ostling A., Green J.L. \& Kinzig A. 2004: Biodiversity conservation: climate change and extinction risk. - Nature 430(6995): 34 . 
HeIJeRman T. \& Turin H. 1994: Towards a method for biological assessment of habitat quality using carabids (Coleoptera, Carabidae). In Desender K., Dufrene M., Loreau M., Luff M.L. \& Maelfait J.-P. (eds): Carabid Beetles: Ecology and Evolution. Kluwer, Dordrecht, pp. 305-312.

Homburg K., Homburg N., Schäfer F., Schuldt A. \& Assmann T. 2013: Carabids.org - A Dynamic Online Database of Ground Beetle Species Traits (Coleoptera, Carabidae). URL: https:// www.carabids.org (last accessed 22 May 2019).

Homburg K., Drees C., Boutaud E., Nolte D., Schuett W., Zumstein P., Von Ruschiowski E. \& Assmann T. 2019: Where have all the beetles gone? Long-term study reveals carabid species decline in a nature reserve in Northern Germany. - Insect Conserv. Div. 12: 268-277.

Horvatovich S. 1994: Small populations of Carabidae and the protection of nature in Hungary. In Desender K., Dufrêne M., Loreau M., Luff M. \& Maelfait J.-P. (eds): Carabid Beetles: Ecology and Evolution. Kluwer, Dordrecht, pp. 313-317.

HŮRKA K. 1996: Carabidae of the Czech and Slovak Republics. Kabourek, Zlín, 565 pp.

Kerr J.T., Kharouba H.M. \& Currie D.J. 2007: The macroecological contribution to global change solutions. - Science 316: $1581-1584$.

KorvULA M.J. 2011: Useful model organisms, indicators, or both? Ground beetles (Coleoptera, Carabidae) reflecting environmental conditions. In Kotze D.J., Assmann T., Noordijk J., Turin H. \& Vermeulen R. (eds): Carabid Beetles as Bioindicators: Biogeographical, Ecological and Environmental Studies. —ZooKeys 100: 287-317.

Kotze D.J. \& O'Hara R.B. 2003: Species decline: but why? Explanations of carabid beetle (Coleoptera, Carabidae) declines in Europe. - Oecologia 135: 138-148.

Krebs C.J. 1989: Ecological Methodology. Harper \& Row, New York, $654 \mathrm{pp}$.

La Sorte F.A. \& Jetz W. 2010: Projected range contractions of montane biodiversity under global warming. Proceedings. Biol. Sci. 277: 3401-3410.

LEATHER S.R. 2017: "Ecological Armageddon" - more evidence for the drastic decline in insect numbers. - Ann. Appl. Biol. 172: $1-3$.

Lindroth C.H. 1961-1969: The ground beetles (Carabidae, exc. Cincindelinae) of Canada and Alaska. Parts 1-6. - Opusc. Entomol. Suppl. 20, 24, 29, 33, 34, 35: 638 pp.

Lindroth C.H. 1985: The Carabidae (Coleoptera) of Fennoscandia and Denmark. Fauna Entomologica Scandinavica 15 (1). Scandinavian Science Press, Copenhagen, 223 pp.

Löver G.L. \& SunderLand K.D. 1996: Ecology and behaviour of ground beetles (Coleoptera: Carabidae). - Annu. Rev. Entomol. 41: 231-256.

LuFF M.L. 1996: Use of Carabids as environmental indicators in grasslands and cereals. - Ann. Zool. Fenn. 33: 185-195.

Maelfait J.P., Desender K. \& Dufrene M. 1994: Carabid beetles and nature conservation research in Belgium: a review. In Desender K., Dufrene M., Loreau M., Luff M.L. \& Maelfait J.-P. (eds): Carabid Beetles: Ecology and Evolution. Kluwer, Dordrecht, pp. 319-323.

McCARTY J.P. 2001: Ecological consequences of recent climate change. - Conserv. Biol. 15: 320-331.

Merivee E., Renou M., Mända M., Luik A., Heidemaa M. \& Ploomi A. 2004: Electrophysiological responses to salts from antennal chaetoid taste sensilla of the ground beetle Pterostichus aethiops. - J. Insect Physiol. 50: 1001-1013.

Merivee E., Ploomi A., Milius M., LuiK A. \& HeidemaA M. 2005: Electrophysiological identification of antennal $\mathrm{pH}$ receptors in the ground beetle Pterostichus oblongopunctatus. - Physiol. Entomol. 30: 122-133.

Merivee E., Märtmann H., Must A., Milius M., Williams I. \& MÄND M. 2008: Electrophysiological responses from neurons of antennal taste sensilla in the polyphagous predatory ground beetle Pterostichus oblongopunctatus (Fabricius 1787) to plant sugars and amino acids. - J. Insect Physiol. 54: 1213-1219.

Must A., Merivee E., Mänd M., Luik A. \& Heidemaa M. 2006: Electrophysiological responses of the antennal campaniform sensilla to rapid changes in temperature in the ground beetles Pterostichus oblongopunctatus and Poecilus cupreus (tribe Pterostichini) with different ecological preferences. - Physiol. Entomol. 31: 278-285.

MÜLLER-Motzfeld G. 1989: Laufkäfer (Coleoptera: Carabidae) als pedobiologische Indikatoren. - Pedobiologia 33: 145-153.

Niemelä J. 2001: Carabid beetles (Coleoptera: Carabidae) and habitat fragmentation: a review. - Eur. J. Entomol. 98: 127132.

Niemelä J., Kotze J., Ashworth A., Brandmayr P., Desender K., New T., Penev L., Samways M. \& Spence J. 2000: The search for common anthropogenic impacts on biodiversity: A global network. - J. Insect Conserv. 4: 3-9.

Niemelä J., Koivula M. \& Kotze D.J. 2007: The effects of forestry on carabid beetles (Coleoptera: Carabidae) in boreal forests. - J. Insect Conserv. 11: 5-18.

Nolte D., Boutaud E., Kotze J., Schuldt A. \& Assmann T. 2019: Habitat specialization, distribution range size and body size drive extinction risk in carabid beetles. - Biodiv. Conserv. 28: 1267-283.

Parmesan C. \& Yohe G. 2003: A globally coherent fingerprint of climate change impacts across natural systems. - Nature 421: $37-42$.

Payne J.L., Bush A.M., Heim N.A., Knope M.L. \& Mccauley D.J. 2016: Ecological selectivity of the emerging mass extinction in the oceans. - Science 353: 1284-1286.

Penev L. 1996: Large-scale variation in carabid assemblages, with special reference to the local fauna concept. - Ann. Zool. Fenn. 33: 49-63.

Pizzolotto R. 1994: Ground beetles (Coleoptera, Carabidae) as a tool for environmental management: a geographical information system based on carabids and vegetation for the Karst near Trieste (Italy). In Desender K., Dufrene M., Loreau M., Cuff M.L. \& Maelfait J.-P. (eds): Carabid Beetles: Ecology and Evolution. Kluwer, Dordrecht, pp. 343-351.

Pizzolotto R., Cairns W. \& Barbante C. 2013: Pilot research on testing the reliability of studies on carabid heavy metals contamination. - Baltic J. Coleopt. 13: 1-13.

Pizzolotto R., Gobbi M. \& Brandmayr P. 2014: Changes in ground beetle assemblages above and below the treeline of the Dolomites after almost thirty years (1980/2009). - Ecol. Evol. 4: 1284-1294.

Pizzolotto R., Albertini A., Gobbi M. \& Brandmayr P. 2016: Habitat diversity analysis along an altitudinal sequence of alpine habitats: the Carabid beetle assemblages as a study model. - Period. Biol. 118: 241-254.

PrugovečKi I. 1997: Geomorphological Characteristics of NP Risnjak. PhD thesis, Faculty of Science, University of Zagreb, pp. 25-26 [in Croatian].

SAUNDERS M. 2017: Insects in Decline: Why we Need More Studies Like This. URL: https://ecologyisnotadirtyword. com/2017/10/20/insects-in-decline-why-we-need-more-studies-like-this/ (last accessed 23 Jan. 2019).

Scalercio S., Bonacci T., Mazzei A., Pizzolotto R. \& BrandMAYR P. 2014: Better up, worse down: bidirectional conse- 
quences of three decades of climate change on a relict population of Erebia cassioides. - J. Insect Conserv. 18: 643-650.

SCHWERK A. 2014: Changes in carabid beetle fauna (Coleoptera: Carabidae) along successional gradients in post-industrial areas in Central Poland. - Eur. J. Entomol. 111: 677-685.

SekercioğLu C.H., Schneider S.H., Fay J.P. \& Loarie S.R. 2008 Climate change, elevational range shifts, and bird extinctions. - Conserv. Biol. 22: 140-150.

SekercioğLu C.H., Primack R.B. \& Wormworth J. 2012: The effects of climate change on tropical birds. - Biol. Conserv. 148: $1-18$.

Šerić Jelaska L. \& Durbešić P. 2009: Comparison of the body size and wing form of carabid species (Coleoptera: Carabidae) between isolated and continuous forest habitats. - Ann. Soc. Entomol. Fr. 45: 327-338.

Šerić Jelaska L., Dumbović V. \& KučInIĆ M. 2010: Carabid beetle diversity and mean individual biomass in beech forests of various ages. - Zookeys 100: 393-405.

Šerić Jelaska L., Jurasović J., Brown S.D., Vaughan P.I. \& SyMONDSON W.O.C. 2014: Molecular field analysis of trophic relationship in soil-dwelling invertebrates to identify mercury, lead and cadmium transmission through forest ecosystems. - Mol. Ecol. 23: 3755-3766.

Shortall C.R., Moore A., Smith E., Hall M.J., Woiwod I.P. \& HARRINGTON R. 2009: Long-term changes in the abundance of flying insects. - Insect Conserv. Div. 2: 251-260.

Sklodowski J. \& Garbalińska P. 2011: Ground beetle (Coleoptera, Carabidae) assemblages inhabiting Scots pine stands of Puszcza Piska Forest: six-year responses to a tornado impact. —Zookeys 100: 371-392.

ŠUSTEK Z. 2013: Results of monitoring of carabid communities in forests damaged by the wind storm in High Tatra Mts. in 2004. In Fleischer P. (ed.): The 5th Windstorm Research - High Tatra Mts. Proceedings from the Scientific International Seminar, Tatranská Lomnica, 23-24 November 2012. TANAP, Tatranská Lomnica, p. 65.

SzyszKo J. 1983: Methods of macrofauna investigations. In: Szyszko J. (ed.): The Process of Forest Soil Macrofauna Formation After Afforestation Farmland. Warsaw Agricultural University Press, Warsaw, pp. 10-16.

Szyszko J., Vermuelen H.J.W., Klimaszewski M. \& Schwerk A. 2000: Mean individual Biomass (MIB) of ground beetles (Carabidae) as an indicator of the state of the environment. In Brandmayr P., Lövei G., Brandmayr T.Z., Casale A. \& Taglianti A.V. (eds): Natural History and Applied Ecology of Carabid Beetles. Pensoft, Sofia, Moscow, pp. 289-294.

TAYlor M.E., Morecroft M.D. 2009: Effects of agri-environment schemes in a long-term ecological time series. - Agricult. Ecosyst. Environ. 130: 9-15.

Terzopoulou S., Rigal F., Whittaker R.J., Borges P.A.V. \& TriANTIS K.A. 2015: Drivers of extinction: the case of Azorean beetles. - Biol. Lett. 11: 20150273, 4 pp.

Thiele H.U. 1977: Carabid Beetles in Their Environments. Zoophysiology and Ecology 10. Springer, Berlin, 369 pp.

Trautner J. \& Geigenmüller K. 1987: Sandlaufkäfer Laufkäfer. J. Margraf, Aichtal, $488 \mathrm{pp}$.

Turin H. 2000: The Dutch Loop Beetles, Diffusion and Ecology (Coleoptera: Carabidae). National Natuurhistorisch Museum Naturalis, KNNV Uitgeverij \& EIS, Leiden, 666 pp. [in Dutch].

Vaibhao G., Varsha S. \& Vishwanath D. 2013: Ground beetles (Coleoptera: Carabidae) of Melghat Tiger Reserve, Central India. - J. New Biol. Rep. 2: 173-176.

Vujčić-Karlo S. 1999: Faunistical and Ecological Research of the Ground Beetles in Different Forest Communities in Croa- tia. PhD thesis, Faculty of Science, University of Zagreb, 256 pp. [in Croatian].

WAGNer D.L. \& LieBherR J.K. 1992: Flightlessness in insects. Trends Ecol. Evol. 7: 216-220.

Wilson R.J., Gutiérrez D., Gutiérrez J., Martínez D., Agudo R. \& MonserRat V.J. 2005: Changes to the elevational limits and extent of species ranges associated with climate change. Ecol. Lett. 8: 1138-1146.

Work T.T., Koivula M., Klimaszewski D.L., Spence J., Sweeney J. \& HÉBERT C. 2008: Evaluation of carabid beetles as indicators of forest change in Canada. - Can. Entomol. 140: 393-414.

Received June 20, 2019; revised and accepted December 17, 2019 Published online February 7, 2020

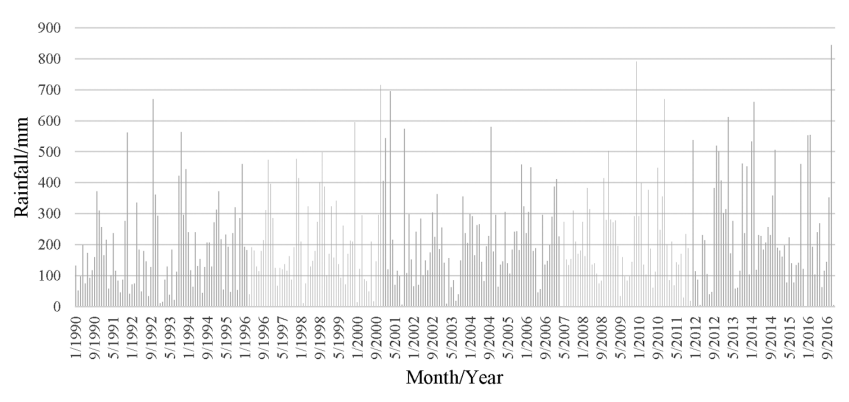

Fig. S1. The 25-years moving mean of the total rainfall recorded at meteorological station Crni Lug, NP Risnjak.

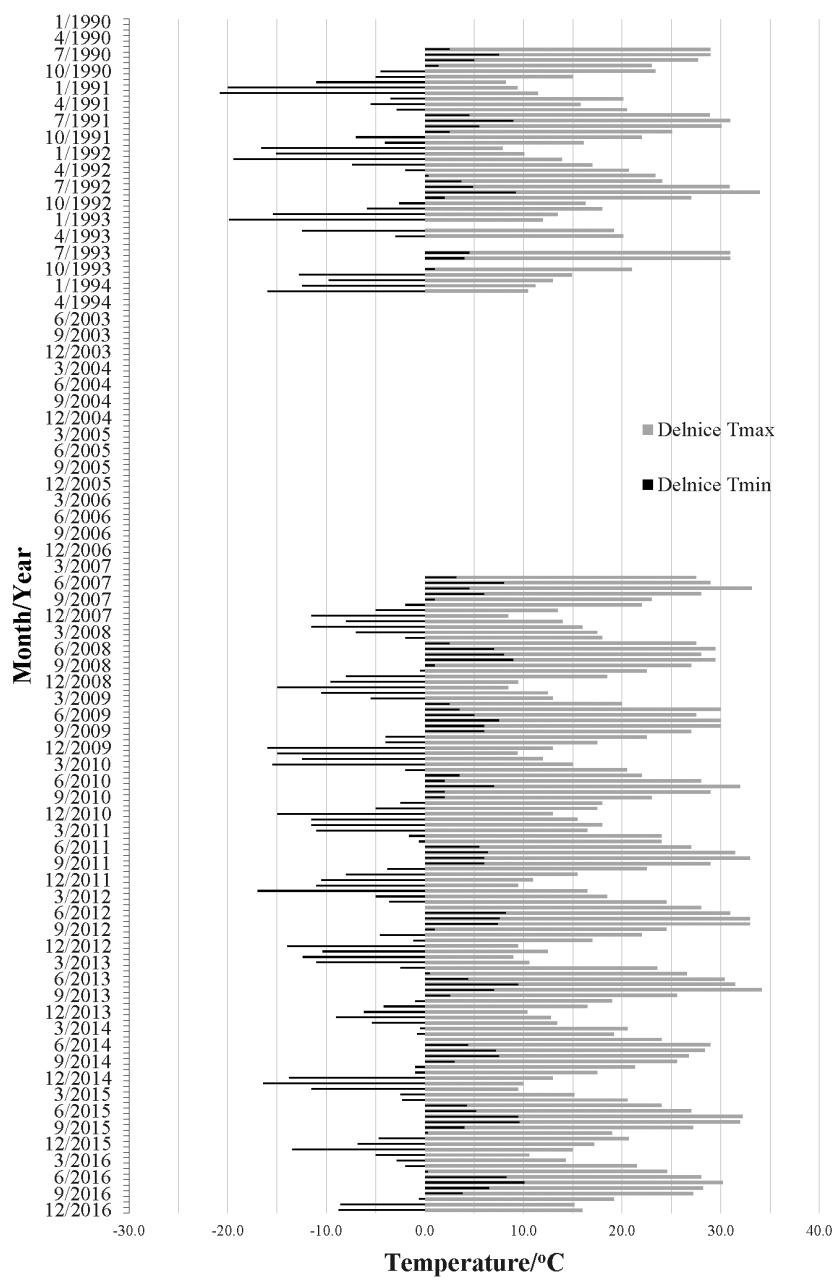

Fig. S2. The 25-year moving average of minimum and maximum monthly temperature recorded at the meteorological station Delnice. 
Table S1. The percentage of individual species per site in years 1990-1991 $\left(\mathrm{L}_{3}^{90 / 91}, \mathrm{~L}_{5}{ }^{90 / 91}, \mathrm{~L}_{8}^{90 / 91}\right)$ and $2015-2016\left(\mathrm{~L}_{1}-\mathrm{L}_{8}\right)$.

\begin{tabular}{|c|c|c|c|c|c|c|c|c|c|c|c|c|}
\hline \multirow{2}{*}{ Species / Site mark } & \multirow{2}{*}{ Abbreviation } & \multicolumn{11}{|c|}{ Pecentage of individuals (\%) } \\
\hline & & $\mathrm{L}_{1}$ & $\mathrm{~L}_{2}$ & $\mathrm{~L}_{3}$ & $\mathrm{~L}_{4}$ & $\mathrm{~L}_{5}$ & $\mathrm{~L}_{6}$ & $\mathrm{~L}_{7}$ & $\mathrm{~L}_{8}$ & $\mathrm{~L}_{8}^{90 / 91}$ & $\mathrm{~L}_{5}^{90 / 91}$ & $\mathrm{~L}_{3}{ }^{90 /}$ \\
\hline Abax parallelepipedus (Piller \& Mitt & Aba. par. & 0.00 & 0.00 & 0.17 & 3.13 & 0.00 & 0.00 & 0.00 & 0.00 & 0.00 & 0.00 & 0.00 \\
\hline rinatus Duftschmid 1812 & ar. & 15 & 1.07 & 0.52 & 0.00 & 00 & 0.00 & 0.00 & 0.00 & 0.00 & 0.00 & 0.30 \\
\hline Abax ovalis Duftschmid 1812 & Aba. ova. & 12.21 & 3.41 & 2.58 & 14.36 & 1.27 & 5.05 & 18.77 & 4.59 & 9.30 & 1.12 & 7.74 \\
\hline Agonum sp. Bonelli 1810 & & 0.14 & 0.00 & 0.00 & 0.00 & 0.00 & 0.00 & 0.00 & 0.00 & 0.00 & 0.00 & 0.00 \\
\hline Anisodactylus intermedius & & 0.00 & 0.00 & 0.17 & 0.00 & 0.00 & 0.00 & 0.00 & 0.00 & 0.00 & 0.00 & 0.00 \\
\hline Amara eurynota Panzer 1797 & Ama. eur. & 0.00 & 0.43 & 0.17 & 0.00 & 0.00 & 0.00 & 0.00 & 0.00 & 0.00 & 0.00 & 0.00 \\
\hline Aptinus bombarda Illiger 1800 & Apt. bom. & 0.29 & 19.83 & 43.72 & 24.86 & 0.05 & 0.03 & 0.00 & 70.09 & 0.08 & 0.00 & 4.70 \\
\hline & & 0.00 & 0.00 & 0.00 & 0.00 & 0.00 & 0.00 & 0.00 & 0.00 & 0.01 & 0.00 & 0.00 \\
\hline Calathus micropterus & & 0.00 & 0.00 & 0.00 & 0.00 & 0.00 & 0.00 & 0.00 & 0.00 & 0.00 & 3.93 & 0.00 \\
\hline Carabus catenulatus Sco & at. & 0.00 & 6.61 & 0.34 & 12.89 & 0.00 & 0.00 & 3.56 & 0.06 & 0,12 & 0.02 & 0.91 \\
\hline & & 1.15 & 0.43 & 0.00 & 0.37 & 0.00 & 0.00 & 0.00 & 0.00 & 0.00 & 0.02 & 0.00 \\
\hline Car & & 1.01 & 13.01 & 3.96 & 18.78 & 0.00 & 0.03 & 12.74 & 0.18 & 0.24 & 0.02 & 0.76 \\
\hline Carabus & & 0.00 & 0.00 & 0.00 & 0.00 & 0.05 & 0.07 & 6.58 & 0.00 & 0.13 & 0.00 & 0.00 \\
\hline & & 0.00 & 1.49 & 69 & 4.79 & 1.06 & 1.21 & 20.41 & 2.69 & 0.81 & 0.2 & 2.73 \\
\hline Car & & 4.74 & 4.48 & 4.99 & 5.71 & 3.33 & 3.09 & 7.81 & 1.41 & 0.05 & 1.95 & 5.61 \\
\hline Cychr & & 2.16 & 2.99 & 1.72 & 1.47 & 0.11 & 0.34 & & 0.37 & 0.6 & 0.86 & 2.73 \\
\hline Cymi & hum. & 0.00 & 0.00 & 00 & .00 & 0.00 & 0.00 & & 0.00 & 0.00 & 02 & 0.00 \\
\hline Hark & & 0.00 & 0.00 & 0.00 & 0.00 & 0.05 & 0.00 & 0.00 & 0.00 & 0.00 & 0.02 & 0.00 \\
\hline Leis & & 0.00 & 0.00 & 0.00 & 0.00 & 0.26 & 0.00 & & 0.00 & 0.00 & 0.00 & 0.00 \\
\hline & & 0 & 0.00 & 17 & 00 & & 0.00 & & 0.00 & 0 & & 0.00 \\
\hline & & 0.00 & 0.64 & 0.00 & 0.00 & 0.00 & 0.00 & 0.00 & 0.06 & 0.39 & 4.57 & 0.76 \\
\hline Leistu & Lei. spi. & 0.14 & 0.21 & 0.17 & 0.00 & 0.00 & 0.00 & 0.14 & 0.00 & 0.15 & 0.00 & 0.00 \\
\hline Licinus hoffmannseggi & Lic. hof. & 0.00 & 0.21 & 0.17 & 0.74 & 0.58 & 0.24 & 0.55 & 0.12 & 0.00 & 0.18 & 0.00 \\
\hline & & 0.14 & 0.00 & 0.00 & 0.00 & 0.00 & 0.00 & 0.00 & 0.00 & 0.00 & 0.00 & 0.00 \\
\hline Molor & & 0.00 & 0.00 & 0.00 & 0.00 & 0.00 & 0.00 & 0.00 & 0.00 & 2.99 & 1.10 & 3.03 \\
\hline Molor & ele. & 0.00 & 0.00 & 0.00 & 0.55 & 1.06 & 0.20 & 0.00 & 0.31 & 0.00 & 0.00 & 0.00 \\
\hline & & 0.00 & 0.00 & 0.00 & 0.00 & 1.48 & 0.10 & 0.00 & 0.06 & 0.00 & 0.00 & 0.00 \\
\hline Molops piceus Panze & & 0.00 & 0.00 & 0.17 & 0.18 & 2.43 & 0.03 & 0.27 & 0.06 & 0.00 & 0.00 & 0.00 \\
\hline Molor & ri. & 1.58 & 0.64 & 2.58 & 2.03 & 0.00 & 1.01 & 0.27 & 0.98 & 0.84 & 0.12 & 3.79 \\
\hline Nebric & & 0.29 & 0.00 & 0.00 & 0.00 & 0.00 & 0.00 & 0.00 & 0.00 & 0.00 & 0.00 & 0.00 \\
\hline Nebric & & 64.08 & 22.81 & 20.31 & 0.18 & 79.83 & 58.73 & 2.33 & 5.08 & 60.75 & 31.35 & 27.4 \\
\hline Notiol & ig. & 0.00 & 0.00 & 0.17 & 0.00 & 1.16 & 0.00 & 0.00 & 0.00 & 0.24 & 2.99 & 0.30 \\
\hline Platynus scrobiculatus Fabric & a. scr. & 0.57 & 0.00 & 2.41 & 0.00 & 0.00 & 0.00 & 0.00 & 0.00 & 0.00 & 0.00 & 1.52 \\
\hline & & 5.75 & 21.75 & 11.53 & 9.94 & 3.80 & 9.65 & 14.25 & 12.11 & 5.01 & 5.32 & 36.87 \\
\hline Pterostichus fasciatopunctatus Creut & & 4.60 & 0.00 & 3.27 & 0.00 & 0.00 & 0.00 & 0.00 & 0.00 & 0.00 & 0.00 & 0.15 \\
\hline Pterostichus unctulatus Duftschmid 1812 & Pte. unc. & 0.00 & 0.00 & 0.00 & 0.00 & 0.00 & 0.00 & 0.00 & 0.00 & 0.03 & 34.34 & 0.00 \\
\hline chus variolatus Dejear & & 0.00 & 0.00 & 0.00 & 0.00 & 3.48 & 20.22 & 11.92 & 1.77 & 18.06 & 9.13 & 0.00 \\
\hline Reicheiodes rotundipennis Chaudoir 1843 & & 0.00 & 0.00 & 0.00 & 0.00 & 0.00 & 0.00 & 0.00 & 0.00 & 0.00 & 0.32 & 0.00 \\
\hline Stomis rostratus Sturm in Duftschmid 1812 & Sto. ros. & 0.00 & 0.00 & 0.00 & 0.00 & 0.00 & 0.00 & 0.00 & 0.06 & 0.14 & 0.66 & 0.15 \\
\hline Trechus croaticus Dejean 1831 & Tre. cro. & 0.00 & 0.00 & 0.00 & 0.00 & 0.00 & 0.00 & 0.00 & 0.00 & 0.07 & 1.75 & 0.46 \\
\hline
\end{tabular}

